\title{
A MAGYAR GÁZPIACI LIBERALIZÁCIÓ 15 ÉVE
}

\section{FIFTEEN YEARS OF GAS MARKET LIBERALISATION IN HUNGARY}

Az első szabadpiaci fogyasztók 2004-es megjelenése óta a gázpiaci értéklánc minden szegmensében jelentős tulajdonosi, szabályozási és múködésbeli változások mentek végbe, eleinte a többszereplős verseny, majd bizonyos szegmensekben az újra erősödő állami szerepvállalással együtt a növekvő koncentráció irányába. Jelen cikk hiánypótló jellegű, mivel nem készült olyan áttekintés a magyar gázpiaci fejleményekről, ami átfogóan mutatná be a 2004-es piacnyitás óta végbement változásokat. Ebben a cikkben a magyar földgázpiaci szabályozás szubjektív, fogyasztói értékelésen alapuló indexét (MPI) és a piacszerkezeti adatok alapján történő szakértői becslésre épülő indexét (ETCR) vetik össze a szerzők, majd a kis- és nagykereskedelmi piaci árak változásának vizsgálatával kiegészítve értékelik a magyar földgázpiaci szabályozás fejlődését.

Kulcsszavak: Magyarország, földgázpiac, szabályozás, belépési korlát, állami tulajdon, vertikális integráció, piacszerkezet, kompozit index, nagykereskedelmi és kiskereskedelmi ár

Since the opening of the natural gas market in 2004, profound changes have taken place in ownership, regulation and operation of the natural gas market. After morphing to a multi-player competition market structure, some market segments returned to strong centralisation and state control. This article enriches the literature on the developments of the Hungarian natural gas market from 2004 as no other analysis has done so far. To describe the history of the sector, the authors compare the indicator of Hungarian natural gas market regulation based on consumer experience (MPI) with the expert evaluation market structure index (ETCR) and the development of wholesale and retail prices.

Keywords: Hungary, natural gas market, regulation, entry barrier, state ownership, vertical integration, market structure, composite index, wholesale and retail price

\section{Finanszírozás/Funding:}

A szerzők a tanulmány elkészítésével összefüggésben nem részesültek pályázati vagy intézményi támogatásban. The authors did not receive any grant or institutional support in relation with the preparation of the study.

\section{Köszönetnyilvánítás/Acknowledgments:}

A szerzők nagyon hálásak és köszönettel tartoznak a kérdőív kitöltőinek és a két anonim bírálónak, illetve mindazoknak a REKK-es kollégáknak és energiapiaci szakértőknek, akik háttérinterjúk során segítették a szabályozás és azok mögötti elvek és szándékok jobb megértését. Az esetleges pontatlanságok a szerzőké.

The authors are very grateful and thank the two anonymous reviewers, as well as the respondents for filling out the questionnaire. They are also grateful to all colleagues of REKK and energy market experts, who helped them to better understand the regulations, its underlying principles and intentions in the background interviews. The authors are responsible for any possible inaccuracies.

\section{Szerzők/Authors:}

Takácsné Tóth Borbála, Budapesti Corvinus Egyetem (borbala.toth@uni-corvinus.hu)

Kotek Péter, REKK (peter.kotek@rekk.hu)

Selei Adrienn, Budapesti Corvinus Egyetem (adrienn.selei@uni-corvinus.hu)

A cikk beérkezett: 2019.07.12-én, javítva: 2019.08.29-én, elfogadva: 2019.09.27-én.

This article was received: 12.07.2019, revised: 29.08.2019, accepted: 27.09.2019. 
A magyar gázpiaci liberalizáció és szabályozás fejlődése az európai uniós irányelvek magyarországi átültetésén alapul. Magyarország Európai Unióhoz történő csatlakozását követően a gáztörvények célja a "biztonságos" és "gazdaságos" gázszolgáltatás mellett kiegészült azzal a kimondott céllal, hogy az egységesülő európai gázpiacokhoz csatlakozva (2008. évi XL tv) versenyző földgázpiacot, átlátható szabályozást kíván létrehozni.

A közgazdasági elmélet szerint a piacnyitással megvalósuló verseny jótékony hatással van az árak alakulására, és mivel a nagykereskedelmi árak csökkenése várhatóan a kiskereskedelemben is érvényesül, a verseny a fogyasztói jólétet és általában a társadalmi összjólétet is növeli (Newbery, 1999). Ez a várakozás volt az, ami miatt az Európai Unióban az egységes piac megteremtésének célját a termékpiacok sikeres egységesítése után a szolgáltatások (vasút, posta, energia, víz és távközlés) piacára is kiterjesztették. Az 1980-as évektől kezdődően egyfajta szakpolitikai konszenzus alakult ki a hálózatos iparágakkal kapcsolatban az USA-ban és Európában, elsősorban három fő paradigma köré csoportosulva: (1) az állam visszavonulása és privatizáció, (2) a vertikális szétválasztás és (3) a piacok liberalizációja (Ceriani, Doronzo, \& Florio, 2009). Ezeknek az elveknek a megvalósításában ugyanakkor szektoronként és régiónként is tapasztalhatók hangsúlyeltolódások.

Az Európai Bizottság stratégiai jellegü dokumentumai és az energiaszabályozási csomagok nem foglalnak állást az állami tulajdon kérdéskörében, mindössze az egyenlő elbánás és a diszkriminációmentesség elvének érvényesülését követelik meg; a részletes kötelezettségeket is tartalmazó szabályrendszer leghangsúlyosabban a második és harmadik pont köré csoportosul. Egyéb nemzetközi szervezetek dokumentumait vizsgálva Ceriani, Doronzo \& Florio (2009) azt találták, hogy az OECD és a Világbank sokkal nagyobb hangsúlyt helyez az állami tulajdon dominanciájával kapcsolatos szabályozói torzítások problémakörének tárgyalására és megszüntetésére.

Több mérési rendszer is készült annak monitoringjára és nemzetközi összehasonlítására, hogy a hálózatos iparágak esetében a szabályozás milyen mértékben ösztönzi a piaci versenyt. Az Európai Bizottság 2014-ig évente publikálta a belső piac fejlődéséről szóló jelentéseit (European Commission, 2014), melyekben a földgáz esetében a következő kulcsindikátorokat vizsgálta: a szereplők száma az importban, a nagy-és kiskereskedelemben, a koncentráció mérésére szolgáló HHI index, a szolgáltatóváltási mutató. Ezt a jelentési feladatot a Bizottságtól az Energiaszabályozók Együttműködési Ügynöksége (ACER) vette át. Az ACER az energiapiaci kiskereskedelmi jelentésében számos további indikátort közöl. 2015-ben megvizsgálta annak a lehetőségét is, hogy kompozit indikátort képezzen a meglévő indikátorokból, ami lehetővé tette az egyes tagállamok piaci müködésének rangsorolását is. Az ARCIindex (ACER Retail Competition Index) (IPA, 2015) három fö komponensből áll: a piacszerkezeti indikátorokból (szolgáltatók száma, ár-összehasonlíthatóság), a piaci szereplők magatartását mérő mutatószámokból (belépés a piacra, szolgáltató- és csomagváltási arány, nem váltó fogyasztók aránya) és a piaci kimeneti indikátorokból (árak eltérése, piaci árrés, fogyasztói elégedettség). Az ARCI érték 2014-es elemzése alapján Magyarország a 24 vizsgált országból a földgázpiaci verseny szempontjából a 22. helyen végzett. Az ACER kiskereskedelmi monitoring jelentései ugyanakkor nem vették át ezt az indexet, továbbra is külön-külön közlik az egyes indikátorokat.

Az Európai Bizottság 2013 óta az úgynevezett MPI (Market Performance Indicator) indikátort is alkalmazza a piacok müködésének mérésére. Az MPI szintén egy kompozit indikátor, mely a piacok müködését a fogyasztók megítélése alapján méri. Az adatokat kérdőíves felméréssel gyűjtik 40 ország termékeinek és szolgáltatásainak piacán. Ennek a kérdőíves felmérésnek a földgázpiacra vonatkozó kérdéseiből képzett MPI-indikátora szerint a 2013-2017 időszakban a magyar lakossági fogyasztók elégedettsége a földgázpiaci szolgáltatással 100-as skálán 23 ponttal nőtt, és mára Magyarország Szlovénia után a második legjobb helyen szerepel a földgázpiaci elégedettségi listán.

Az OECD szintén kialakított egy több szektorra is alkalmazott indexet (ETCR-index: Energy, transport and telecommunication regulatory indicator) a szabályozás hatékonyságának mérésére. Az ETCR segítségével lehetővé vált a szabályozás hosszabb időtávon történő változásának index formájába sürített bemutatása, továbbá annak összehasonlítása is, hogy mely országok szabályozása támogatja inkább a versenyt (Conway \& Nicoletti, 2006). Ez az indikátor is kérdőíves adatgyüjtésen alapszik, de a kérdőívet a szabályozó hatóságok, minisztériumi tisztviselők és a szektorban dolgozó szakértők töltik ki a szabályozásra vonatkozó kérdésekre adott pontozással. A 2013-ig rendelkezésre álló adatok alapján Magyarország földgázpiaci szabályozása fokozatosan egyre nyitottabbá és piacbarátabbá vált az európai uniós szabályozási csomagok implementálásával.

A cikk célja, hogy a magyar földgázpiaci szabályozás szubjektív, fogyasztói értékelésen alapuló indexét (MPI) és a szakértői, piacszerkezeti adatokon alapuló mérési indexét (ETCR) összevesse, és a kis- és nagykereskedelmi piaci árak változásának vizsgálatával kiegészítve értékelje a magyar földgázpiaci szabályozás fejlődését. Ehhez nélkülözhetetlen Magyarország ETCR-indikátorának becslése a 2014-18 közötti időszakra, melyet az OECD-módszertan alapján, szakértői értékelés segítségével végzünk el.

A cikk első fejezete összefoglalja a magyar földgázpiac fejlődésével kapcsolatos hazai és nemzetközi szakirodalmat, a második fejezet a cikkben alkalmazott módszertant mutatja be, a harmadik fejezet bemutatja az ETCR-indikátort és értékeinek becslését a 2014-2018 közötti időszakra, és ezzel párhuzamosan elemzi a hazai szabályozási környezet változását. Ezt követően a negyedik fejezet bemutatja az MPI-indikátort, majd az ötödik fejezet a gázárak változását. A hatodik fejezet végül az indikátorok összevetéséből adódó lehetséges következtetéseket és szakpolitikai ajánlásokat tárgyalja.

\section{Szakirodalmi háttér}

„A magyar földgázszektor müködése és szabályozása” kötet foglalja össze legrészletesebben a magyar földgázpiaci szabályozást. A kötet technikai, jogi és piacszabályozási részletekre is kitér, különösen az árszabályozással 
kapcsolatos fejezete (Farkas, 2014) releváns jelen cikk szempontjából, ami bemutatja a földgázpiaci ár- és tarifaszabályozásban követett elveket és gyakorlatot 2014-ig.

A vertikálisan integrált állami tulajdonú tröszt, az OKGT privatizációra való felkészítéséről az 1990-es évek elején, majd 1995-ben az állami tulajdon külföldi szakmai befektetők részére való értékesítéséről Mihályi ír részletesen (Mihályi, 2010). A privatizáció motivációi elsősorban a költségvetési bevételek növelése, a vállalatok hatékonyságának javítása és a nemzetközi know-how bevonzása voltak. A szektor szabályozási szerveként 1994-ben hozták létre a Magyar Energia Hivatalt. A Hivatal éves beszámolói fontos dokumentumai a szektor fejlődésének (MEKH, 2019c).

A Verseny és Szabályozás évente megjelenő kötetei folyamatában vizsgálják a hálózatos piacok - köztük a gázpiac - szabályozási és versenypiaci helyzetének változásait. Vince Péter (2011) elemzése a piacnyitás első éveinek dilemmáival foglalkozva megállapítja, hogy elsősorban az európai uniós szabályozási csomagok hazai implementációja volt a szabályozási változások motorja 2010-ig.

Valentiny Pál 2008-ban az ETCR-indexet, mint a hálózatos piacok szabályozási indikátorát mutatja be több szektorra magyar fókusszal, köztük a földgázpiaci szabályozást az óvatosan haladók táborába sorolva (Valentiny, 2009).

A szabályozás változása hatással volt a vállalati szektor szerkezeti felépítésére is, melyet Horánszky Bernadett vizsgált a privatizációtól a teljes piacnyitásig. Megállapította, hogy a külföldi szakmai befektetők új, a nyugati vállalati kultúrához, illetve a piacgazdasági környezethez igazodó stratégiákat fogalmaztak meg, melynek céljaihoz igazították a társaságok struktúráját. A szerző szerint a legnagyobb változást az európai szabályozási csomagoknak való megfelelés hozta: 2004től a tevékenységszétválasztás funkcionális (menedzseri) szinten zajlott, majd a 2007-es teljes piacnyitás után jogi szétválasztásra került sor: a gázellátó társaságok tevékenységi köréből kikerül a gázkereskedelem, s kizárólag a gáz útját biztosító infrastruktúra müködtetését végzik. Létrejöttek az infrastruktúrát üzemeltető és a tőlük jogilag független kereskedő társaságok (Horánszky, 2006).

Konszenzus van a szerzők között abban a kérdésben, hogy 2009-ig a magyarországi szabályozás elsődleges húzóerejét az európai uniós szabályozási csomagok kötelező hazai megvalósítása biztosította.

2010 után azonban megjelenik két fontos, politikai kezdeményezésre végrehajtott fordulat. 2010-et követően az állam tudatos stratégiát követve növelte tulajdonosi szerepét a földgázpiaci infrastruktúra üzemeltetés és a kereskedelem terén is, a Magyar Villamos Müveket (MVM) téve meg az állami stratégia legfőbb megvalósítójává. 2013-ban az E.ON gáztárolóinak megvásárlásával a tárolói mobil-gázkapacitások 70\%-ának birtokosaként az MVM lett a legnagyobb tárolóiinfrastruktúra-üzemeltető és egyben a legnagyobb kereskedő is: az E.ON Földgázkereskedő megvásárlásával a kereskedett földgázmennyiség alapján az MVM részesedése a 2010-es közel nulláról hirtelen 50 százalék fölé emelkedett (MEKH, 2014).
Ezt követően 2015 és 2016 során a korábbi hét egyetemes szolgáltató közül négy visszaadta működési engedélyét, és mára az NKM Földgázszolgáltató Zrt. (az MVM csoport tagja) a magyarországi gázfogyasztók 99\%-ának ellátója, és az egész ország területén nyújt egyetemes szolgáltatást (MEKH, 2019c). Ezzel párhuzamosan a legtöbb volt egyetemes szolgáltató társaság versenypiaci földgáz-kereskedelmi tevékenységét is felszámolta, felhasználóit más szereplöknek, többnyire szintén az NKM Földgázszállító Zrt-nek adta át. A hazai kiskereskedelmi piacon 2019 közepére az MVM-csoport piaci részesedése 70-80 százalék körülire nőtt.

A másik jelentős, szabályozási beavatkozás az állami kontroll erősödő bevezetése, amely az energetikáért felelős miniszter jogkörébe emelve (2010. évi LV. törvény) központosította az egyetemes szolgáltatási ár megállapítását. A rezsicsökkentés politikai programja 2012 után három lépcsőben csökkentette az egyetemes szolgáltatói körben a végfogyasztói árakat a villamos energia, a földgáz és a távhő körében is. A földgáz árát az egyetemes szolgáltatói körben 2013. január elsejétől 10\%-kal, majd 2013. november elsejétől újabb 11,1\%-kal, majd 2014. április elsejétől további 6,5\%-kal csökkentették. Ezzel a lépéssel Magyarország vásárlóerő-paritáson az egyik legdrágább lakossági gázártól az Európai Unió egyik legolcsóbb lakossági gázárához jutott el. A környező országok gázárainál a lakosság 30-40\%-kal kevesebbet fizetett 2016-ban, miközben az ipari fogyasztói szegmensben az árak együtt mozogtak a régió áraival. Az alacsony árak azonban nem nyújtottak fedezetet a szolgáltatók indokolt költségeire, ami miatt az IEA és az Európai Bizottság is figyelmeztette Magyarországot (IEA, 2017). Vince nem az egyetemes szolgáltatói árcsökkentés indokolhatóságát kérdőjelezi meg, hanem arra mutat rá, hogy a szabályozó által alkalmazott eszközök a 2010-es modellváltás előtti gyakorlatot tükrözik. Ilyen kifogásolható eszköz például a hatósági árrögzítés, a költségnövekedés késleltetett érvényesítése, valamint (2012. januárban) a csak az inflációt követő, de a szektor költségeinek alakulásától eltekintő áremelés (Vince, 2012). A REKK (Kotek, Szajkó, Mészégetőné Keszthelyi, \& Szabó, 2013) elemzésében arra jutott, hogy a nagykereskedelmi árváltozásokat a földgáz végfelhasználói ára nem követte. A második rezsicsökkentés kapcsán megvizsgálták, hogy a rezsicsökkentés milyen mértékben rótt terheket az egyes piaci szereplökre (Kotek \& Szabó, 2014).

A rezsicsökkentés sértette az árdiszkrimináció tilalmát például azzal, hogy az egyetemes szolgáltatói szegmens kedvezőbb áron férhetett hozzá az infrastruktúrához, mint a kereskedők, és ez kötelezettségszegési eljárást is maga után vont. Végül a 2017. január elsejével megkezdődött új árszabályozási ciklus vezette ki a „kettős rendszerhasználat" ármoratórium fenntartása érdekében bevezetett rendszerét (MEKH, 2019c). A fokozódó állami beavatkozás a magánszektor vállalataira is hatással volt: a vállalatok szabályozási kockázatokra adott szervezeti válaszait részletesen vizsgálta Felsmann Balázs (2018).

Tudomásunk szerint nem készült még akadémiai jellegü tanulmány arról, hogy mindezen szabályozói válto- 
zások hogyan hatottak a földgázpiaci versenyre Magyarországon. A nemzetközi szakirodalomban ugyanakkor számos tanulmány vizsgálta, hogy a földgázpiaci reformok milyen hatással voltak a gázárakra.

Brau és munkatársai (2010) 15 európai uniós tagállam esetében panel ökonometriai módszerekkel vizsgálták, hogy milyen összefüggés van a szabályozási reformokat megragadó OECD által számszerüsített ETCR-indikátor és a háztartások által fizetett gázárak alakulása között. Eredményeik azt mutatják, hogy a földgázpiaci reformok hatása a fogyasztói árakra elhanyagolható mértékü. Florio (2014) egy másik tanulmányában a fenti ökonometriai elemzés alapján arra a következtetésre jut, hogy a vertikális szétválasztásnak nincs statisztikailag kimutatható hatása az árakra, illetve, hogy az inkumbens vállalatok állami tulajdonlása a háztartások számára alacsonyabb gázárral jár együtt.

Growitsch \& Stronzik (2014) 18 európai országban történő vizsgálata alapján a szállítási rendszerüzemeltető tulajdonosi szétválasztásának nem volt szignifikáns hatása a kiskereskedelmi földgázárakra, a vertikális integrációt megszüntető jogi/számviteli szétválasztás azonban jelentős kiskereskedelmi árcsökkenést hozott. Hasonló módon árcsökkentő hatással bírt a harmadik feles hozzáférés bevezetése.

Brandão, Pinho, Resende, Sarmento \& Soares (2016) formális Cournot modellel mutatják be, hogy a tulajdonosi szétválasztás a fogyasztók számára magasabb árakat eredményezhet, mint a jogi szétválasztás.

Opolska (2017) az európai földgázpiaci liberalizáció hatásait mérte panel ökonometriai modellekkel, elemzése szerint a liberalizációs szakpolitikák növelik a verseny mértékét.

Bastianin, Castelnovo \& Florio (2018) 63 ökonometriai írás metaanalízisét végzi el, melyek különböző indikátorokat (például az ETCR-indexet) használtak a különböző szabályozási reformok hatásának elemzésére a hálózatos iparágakban. A feldolgozott tanulmányok alapján számos módszertani csapdára hívják fel a figyelmet, ugyanakkor következtetésük szerint az indikátorok többletinformációval szolgálnak a szabályozó felé, ezzel is javítva a szabályozás minőségét.

Herweg, Wurster \& Dümig (2018) szerint a liberalizáció önmagában a piacszerkezetre van hatással, de ez nem eredményezi szükségszerüen a végfogyasztói árak csökkenését, mivel a földgázpiacon az európai szabályozás a nagykereskedelmi árrés "csökkenése" és az intenzívebb verseny ellenére nem hozta el a kiskereskedelmi árak csökkenését.

Egy, az amerikai árampiacokról készített tanulmány (Zummo, 2018) összehasonlította a 1997-2017 közötti, a liberalizált piacú és a vertikálisan integrált, végfogyasztói szabályozású államokban tapasztalt árakat. A szabad szolgáltatóválasztás és a szétválasztás 1997-ben kezdődött és tipikusan azok az államok döntöttek mellette, melyekben eleve magasabbak voltak az áramárak. Az volt a várakozás, hogy a kiskereskedelmi verseny árcsökkenéshez vezet. Ezzel szemben 20 év tapasztalata után azt láthatjuk, hogy a különbség gyakorlatilag nem változott, miközben mindkét szabályozás mellett nőttek az árampiaci árak. A hagyományos ársapka-szabályozás tehát képes volt tartósan alacsony szinten tartani az árakat a vertikálisan integrált szolgáltatókkal szemben is, míg a szétválasztáson alapuló kis- és nagykereskedelmi piaci verseny ebben a tekintetben nem bizonyult hatékonyabbnak.

Látható, hogy a szakirodalomban nincs konszenzus azzal kapcsolatban, hogy a szabályozás mely elemei milyen mértékben hatnak a versenyre, illetve a fogyasztói árakra.

Jelen cikk ehhez a diskurzushoz kíván hozzájárulni azzal, hogy a magyar földgázpiac elmúlt 15 évben történt szabályozási változásait vizsgálja, elsősorban abból a szemszögböl, hogy a szabályozás mennyire támogatta a versenypiac kialakítását. Az elérhető adatok segítségével a szektorra jellemző fogyasztói elégedettséget is bemutatja. Végül a magyarországi földgázárak és a végfogyasztói árszabályozás vizsgálatával tesz kísérletet a szabályozás és a fogyasztói elégedettség közötti összefüggés értelmezésére.

\section{Módszertan}

A magyar földgázpiaci szabályozás értékeléséhez első lépésben az OECD ETCR-indexét használjuk, mely 34 ország hét hálózatos iparágát vizsgálja 1975 és 2013 között. Ennek az indexnek a földgázpiaci komponense segítségével nemzetközi összehasonlításban, longitudinálisan vizsgáljuk a magyar földgázpiaci szabályozást. Az OECD módszertanát és kérdőívét (OECD, 2019) alapul véve a 2014-2018 időszakra megbecsüljük az ETCR-indikátor magyar földgázpiacra vonatkozó komponensét.

A kérdőívet elküldtük a földgázpiaci szabályozással foglalkozó munkatársaknak az illetékes minisztériumba (Innovációs és Technológiai Minisztérium) és a szabályozó hatósághoz (Magyar Energetikai és Közmű-szabályozási Hivatal). A REKK szabályozással foglalkozó szakértői is kitöltötték a kérdöívet. Ily módon 6 válaszadó (1 minisztérium, 3 szabályozó, 2 szakértő) pontozása alapján becsültük meg az ETCR-index értékét 2014-2018 között. A kitöltési útmutató szerint a kérdéseket egy 3 fokozatú skálán kell megválaszolni, ahol a lehetséges válaszértékek 0,3 és 6 pont. Ezt annyiban módosítottuk, hogy a válaszadók köztes értékeket is megadhattak, amennyiben ezt indokolták. A kérdőívek kitöltését követően telefonos vagy személyes interjúkon keresztül is pontosítottuk a pontozásokhoz kapcsolódó információkat.

A végleges pontozáskor elöször kategóriánként átlagoltuk a pontokat (amennyiben több válaszadónk volt), majd a három kategória (szabályozói, minisztériumi, szakértői) pontozásának átlagát vettük figyelembe.

Valentiny (2009) ugyanakkor arra figyelmeztet, hogy bár tendenciák és nemzetközi összehasonlítás szempontjából hasznos lehet ezen indikátor használata, óvatosan kell bánni vele, mivel az egyes országokra jellemző szektorális szabályozási specifikumok ismerete nélkül téves következtetések is levonhatók belöle. Éppen ezért, nem csupán magát az indikátort becsüljük meg, hanem az index egyes komponenseit is részletesebben megvizsgáljuk a magyar szabályozás helyzetének áttekintéséhez, melynek során piaci tényadatok elemzésére is támaszkodunk. 
Ezen túlmenően elemzésünket kétféle módon egészítjük ki. Egyrészt megvizsgáljuk egy szubjektív, a fogyasztói elégedettséget mérő indikátor, az MPI (Market Performance Index) alakulását. Másrészt, mivel az ETCR- és az MPI-indikátor fö hiányosságának azt tartjuk, hogy a piaci árak alakulását nem veszi figyelembe, elemzésünket kiegészítjük a kis- és nagykereskedelmi árak alakulásának vizsgálatával.

\section{AZ ETCR-mutató}

Az OECD ETCR-adatbázisában hét szabályozott iparág, a távközlés, a villamos energia, a gáz, a posta, a vasút, a légi személyszállítás és a közúti fuvarozás adatai találhatók meg. Az indikátor célja, hogy a jogi és szabályozási környezetet mérhetővé tegye, kvalitatív adatokból összehasonlításra alkalmas, mennyiségi mutatószámokat képezzen. A mutatószámokkal ilyen módon a hatékonyságnövelést és a piacra való belépés megkönnyítését célzó szabályozást értékelik.

Mielőtt rátérünk az indikátor 2014 utáni időszakra becsült értékeinek részletes elemzésére, röviden bemutatjuk a földgázpiaci indikátor főbb komponenseit és alakulását 2013-ig.

A mutató minden szektorra vonatkozóan ugyanazt a négy fö témakört vizsgálja: belépési korlátok, az állami tulajdon aránya, a vertikális integráció mértéke, piacszerkezet. Ezekből az almutatókból súlyozással képezik az ágazati szintű mutatókat. A földgázpiac esetében egyforma súllyal szerepel minden almutató. Minden almutató három kérdésből áll, melyek azonos súllyal szerepelnek az almutatókban (1. ábra).
Az ETCR tehát egy olyan kompozit indikátor, mely a szabályozási elvek mentén 0-6 skálán értékeli a piaci szabályozást. A 0 érték a verseny számára teljes mértékben nyitott piacot jelent, míg a 6-os érték az állami tulajdonú vertikálisan integrált monopóliumot, a verseny teljes hiányát takarja.

2. ábra Az ETCR-mutató értéke az Európai Unió országaiban

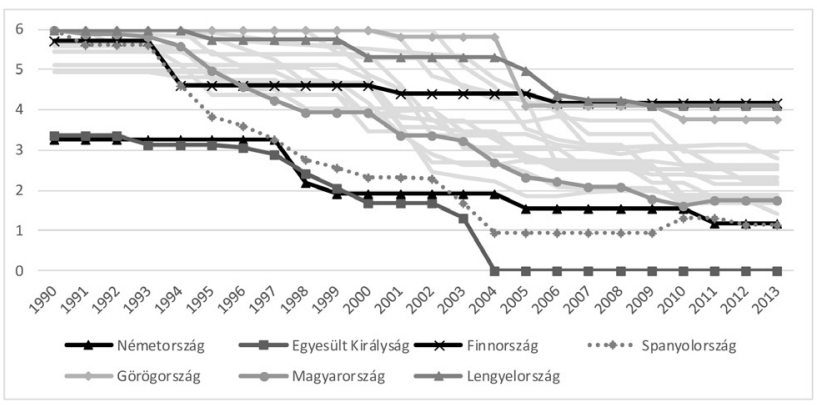

Forrás: saját ábra OECD-adatok alapján

Az 1990-es rendszerváltást követően az első nagyobb változást a regionális szolgáltatók külön vállalatba szervezése, majd 1995-ös privatizációja jelentette. Ezzel a korábbi állami tulajdonú teljesen vertikálisan integrált monopólium felöl (ami a 6-os pontérték) fokozatosan megindult a piaci múködés és a verseny kialakítása felé a szabályozás (Mihályi, 2010; Vince, 2012). A 2. ábrán bemutatottETCR földgázpiaci mutató alapján Magyarország a szabályozás szempontjából eleinte az óvatosabban haladó erős középmezőnyhöz tartozik, majd 2003 után fokozatosan a legpiacbarátabb országok csoportjába kerül. A

1. ábra Az ETCR-mutató felépítése

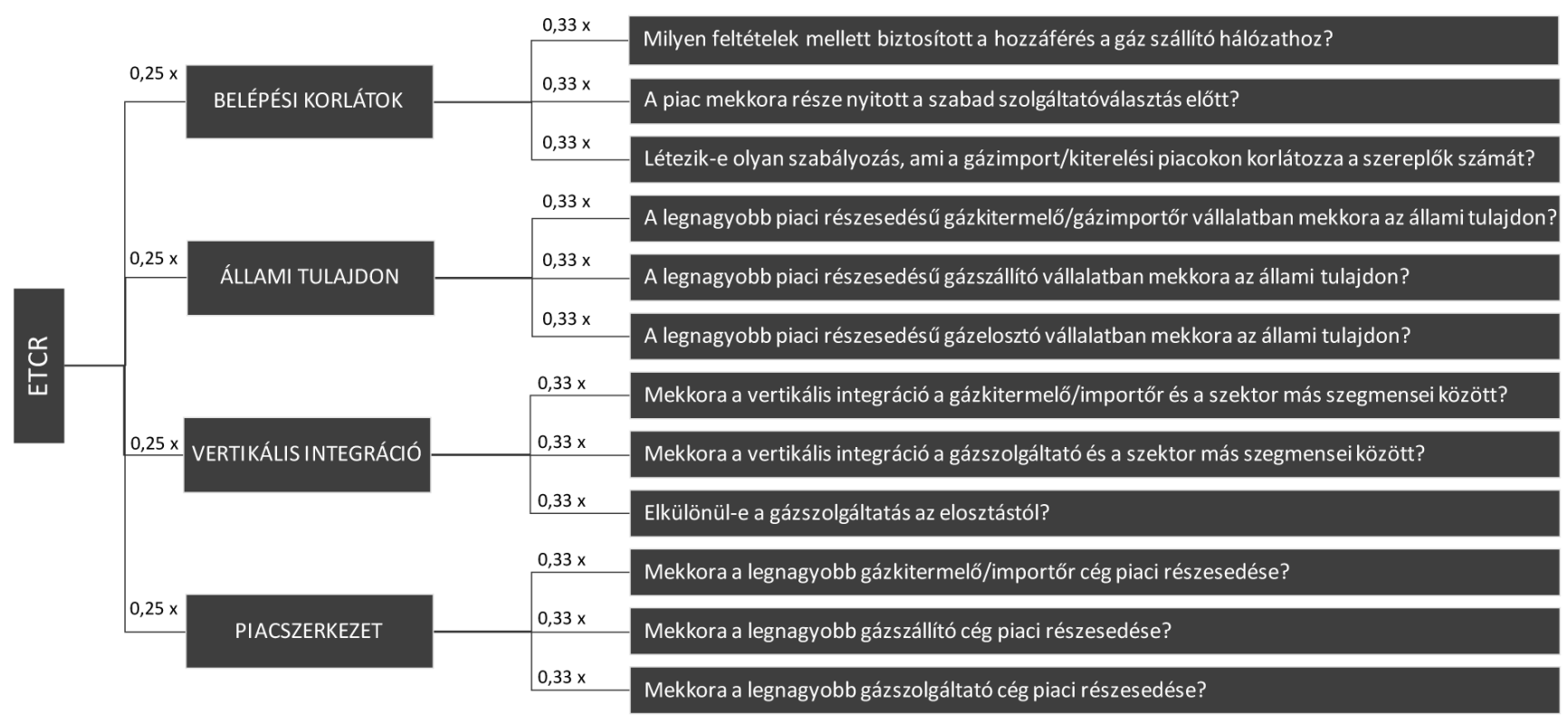

Forrás: saját ábra ETCR-kérdőív alapján 
2003-as gáztörvény megteremtette a versenypiaci müködés kereteit, és feljogosította a nagy ipari fogyasztókat a szabad kereskedőváltásra. A jogi szétválasztás, a teljes piacnyitás és a kötelező szabadpiaci kereskedés a nem lakossági fogyasztók számára 2007 júliusától szintén jelentős lépést jelentett (Farkas, 2014). Az index értéke 2010-ben volt a legalacsonyabb, ekkor vezették be ugyanis a közüzemi szolgáltatás helyett az egyetemes szolgáltatói modellt, ami a leginkább piaci elvü szabályozása volt a magyar földgázpiacnak. Ebben az időben Magyarországnál csak Németországban, Spanyolországban és az Egyesült Királyságban volt piacbarátabb a szabályozás. A rangsor élén szereplő (még) EU-tagország Egyesült Királyság gázszektora nem meglepő módon a legnyitottabb, míg a legkevésbé nyitott Finnországé, Görögországé és Lengyelországé 2013-ban. Az ETRC-index értéke 2013-ig csak Spanyolországban emelkedett (European Commission, 2014).

\section{Az ETCR-indikátor becslése 2013 után}

Ahhoz, hogy az indikátor 2013 utáni értékeit kiszámíthassuk, az OECD-módszertant követve a kérdéseket a szabályozó hatóság (MEKH) munkatársai és a minisztérium (ITM) munkatársai is kitöltötték, valamint a REKK szakértői is pontoztak. A kérdések értelmezése során a pontozásban megjelenő különbségek a válaszadók értelmezési különbségeit mutatják, melyek részletesebb tárgyalása a versenyhelyzet jobb megértését is szolgálja.

A következőkben a földgázpiaci ETRC-indikátor négy fó komponensét külön-külön vizsgáljuk meg, majd bemutatjuk az index összesített értékét.

\section{Belépési korlátok}

Az első komponens a belépési korlátokat vizsgálja a hálózathoz, a fogyasztóhoz és a forrásokhoz való hozzáférés szempontjából. Mindhárom kérdésben érdemes áttekinteni, hogy milyen főbb változások történtek a szabályozásban, illetve a piac müködésében milyen anomáliákat figyelhettünk meg (1. táblázat).

\section{1. táblázat A belépésikorlát-mutatók}

\begin{tabular}{|l|l|l|l|l|l|l|}
\hline & $\begin{array}{l}\text { Lehetséges } \\
\text { válaszok }\end{array}$ & 2014 & 2015 & 2016 & 2017 & 2018 \\
\hline $\begin{array}{l}\text { Milyen feltételek } \\
\text { mellett biztosított a } \\
\text { hozzáférés a gázszállító } \\
\text { hálózathoz? }\end{array}$ & $\begin{array}{l}\text { rTPA(0)/nTPA(3)/ } \\
\text { No TPA (6) }\end{array}$ & 0,11 & 0,11 & 0,11 & 0,11 & 0,11 \\
\hline $\begin{array}{l}\text { A piac mekkora } \\
\text { része nyitott a szabad } \\
\text { szolgáltatóválasztás előtt? }\end{array}$ & $\begin{array}{l}\text { (1-versenyzői piac } \\
\text { részaránya/100)*6 }\end{array}$ & 1,16 & 1,40 & 1,64 & 1,64 & 1,64 \\
\hline $\begin{array}{l}\text { Létezik-e olyan állami } \\
\text { szintủ vagy helyi } \\
\text { szabályozás, ami a } \\
\text { gázimport/-kitermelési } \\
\text { piacokon korlátozza a } \\
\text { szereplők számát? }\end{array}$ & $\begin{array}{l}\text { Nincs (0)/igen, } \\
\text { néhány piacon } \\
\text { (3)/Igen, minden } \\
\text { piacon (6) }\end{array}$ & 1,22 & 1,33 & 1,33 & 1,33 & 1,33 \\
\hline
\end{tabular}

A hálózatos piacok versenypiaci szabályozásának alapvetése, hogy a természetes monopóliumnak tekinthető nagynyomású gázszállító csővezeték-hálózathoz minden szereplő azonos feltételekkel, diszkriminációmentesen hozzáférhessen. A szállítóvezetékek esetében a tarifáknak is szabályozottnak kell lenniük a leginkább versenybarát 0 pont eléréséhez.

Itt tehát két feltételt kell vizsgálni, először is, hogy a tarifa szabályozott-e, másodjára pedig, hogy biztosított-e hálózati hozzáférés. Az úgynevezett szabályozott harmadik feles hozzáférést már a 2003. évi XLII. törvény is elöírtai . A tarifa megállapításának módszertana és a tarifák kihirdetésének módja az európai uniós jogszabályoknak való megfelelést tükrözi (Farkas, 2014). Az összehangolt európai tarifaszerkezetre vonatkozó üzemi és kereskedelmi szabályzat ${ }^{\text {ii }}$ 2018-as bevezetése ebböl a szempontból is növelte a transzparenciát, hiszen a módszertan és a számítás is megismerhető (MEKH, 2019b).

A kapacitásokhoz való hozzáférés elsősorban akkor kritikus, ha valamely ponton fizikai vagy szerződéses okokból egy kereskedő nem tud kapacitásokat foglalni. A szerződéses torlódás akkor áll elő, amikor valamely szereplő a kapacitásokat hosszú távra lekötötte, de azokat nem használja, ugyanakkor nem is értékesíti másodlagos piacokon, szándékosan viszszatartja, hogy ezáltal a versenytársakat távol tartsa a piactól, ahol magasabb árakat idézhet így elő. Ekkor az infrastruktúra alacsony kihasználtsága mellett is előállhat az a helyzet, hogy kereskedelmi tranzakciók meghiúsulnak. Ez a fajta kapacitásvisszatartás nem jellemző a magyar piacon (ACER, 2017), mivel jelenleg nincsenek, és a szabályozó hatóság megelőző intézkedéseinek köszönhetően a kereskedelem szempontjából kulcsfontosságú osztrák-magyar és szlovák-magyar pontokon nem is lesznek a közeljövőben hosszú távú lekötések (MEKH, 2019c; Kotek \& Takácsné Tóth, 2017).

A fizikai szükösség egyetlen határkeresztező pont esetében vetett fel kérdéseket a piacnyitás óta. A 2010-es évek fordulóján a jelentős nagykereskedelmi árkülönbözet miatt nagy kereslet mutatkozott az osztrák-magyar belépési pont (Mosonmagyaróvár) kapacitásai iránt. Ebben az időszakban a nagyon értékes kapacitások kiosztása diszkriminatív módon történt (Szolnoki, 2011), mely gyakorlatot a kapacitáskiosztási üzletszabályzat hatályba lépése szüntette meg 2015-ben. Részben ennek eredményeként a 2014-2018-as időszakban jelentősen csökkent a Mosonmagyaróvár határponton a fizikai torlódás. A 3. ábrán az is jól látható, hogy 2010-15 között a Mosonmagyaróvár belépési ponton a tényleges fizikai szállítás meghaladta a meghirdetett fizikai kapacitást. Ezt a szisztematikus túlhasználatot is részben nem átlátható módon, megszakítható kapacitásként osztották ki. Ez az az időszak, amikor a nyugati nagykereskedelmi piaci ár (TTF) és a magyar nagykereskedelmi ár különbözete miatt a kapacitás birtoklása piaci értékkel bírt.

3. ábra Lekötések és földgázáramlások alakulása Mosonmagyaróvár (AT>HU) belépési ponton, illetve a magyar nagykereskedelmi gázár és a spot TTF gázár viszonya

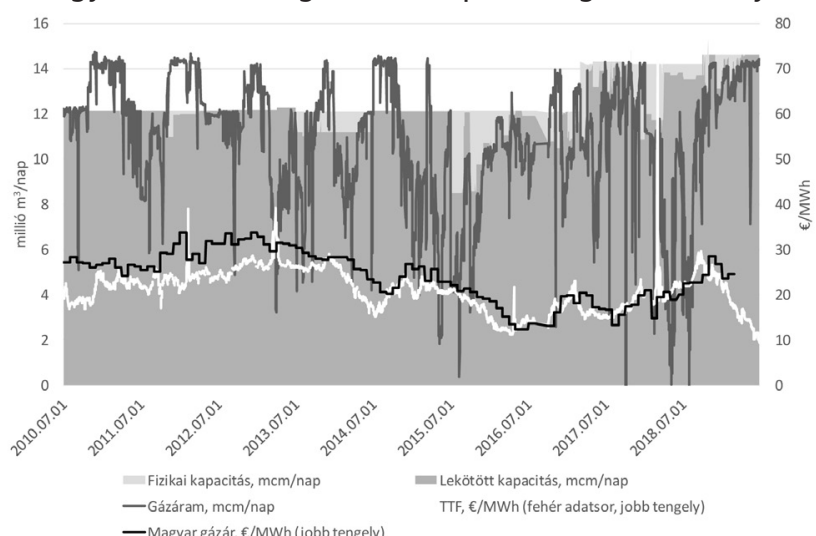

Forrás: FGSZ, Eurostat, TTF alapján REKK 
Az első kérdésre vonatkozóan („Milyen feltételek mellett biztosított a hozzáférés a gázszállító hálózathoz? Szabályozott harmadik feles=0") a válaszadók többsége 0 értéket adott a 2014-18-as időszakra.

A 0,11-es átlagpontszám oka, hogy az infrastruktúrához való hozzáférés egyes részletszabályai időről időre elönyben részesítenek bizonyos fogyasztói köröket. A rezsicsökkentést követően 2017-ig például az egyetemes szolgáltatási szegmens alacsonyabb tarifát fizetett az infrastruktúra használatáért.

A második kérdés: „A piac mekkora része nyitott a szabad szolgáltatóválasztás előtt?" már jobban megosztotta a válaszadókat. Voltak, akik a törvényi felhatalmazás alapján (mindenki jogosult) 100\%-ot tekintettek feljogosított fogyasztónak. Mások úgy látták, hogy az államilag szabályozott egyetemes szolgáltatói ár miatt nem alakulhat ki verseny a lakossági fogyasztókért. Így de facto a háztartási fogyasztók ajánlatok hiányában nem tudnak élni a szabad szolgáltatóváltási jogukkal. A kérdésre a válaszadók átlagos pontszáma a 2014-es 1,16-ról 2018-ra 1,64-re nőtt.

A kiskereskedelmi szegmensben az egyetemes szolgáltatásra jogosult fogyasztók kivételével minden fogyasztó a szabadpiacon vásárol, mely piacon nincsen állami végfogyasztói árszabályozás. A szabadpiaci szegmensben valóban sokszereplös verseny zajlik, és a szereplök száma folyamatosan nő (MEKH, 2019c). Ugyanakkor a 2004-es piacnyitás óta a háztartási fogyasztók esetében csak időszakonként láttunk új szereplőket megjelenni: ilyen volt az EMFESZ és a Magyar Telekom. Az árak 2010-es befagyasztása az egyetemes szolgáltatási rendszerben azonban véget vetett ennek a folyamatnak, a piaci szereplők az egyetemes szolgáltatási engedélyüket 2015-től sorban visszaadták és több lépcsőben az összes lakossági fogyasztó a Nemzeti Közmüszolgáltatóhoz került (MEKH, 2018). Az egyetemes szolgáltatói szegmensben tehát de jure lehetséges a verseny: amennyiben az államilag szabályozott ár tartósan a versenypiaci ár fölé kerül. Azonban a rezsicsökkentések kétségtelenül elbizonytalaníthatták a potenciális új belépőket.

A harmadik kérdés a belépés témakörében arra vonatkozott, hogy van-e olyan jogszabály, ami kifejezetten akadályozza a versenytársak megjelenését bizonyos piaci szegmensekben. Itt a válaszadók egy része a végfogyasztói árszabályozást az egyetemes szolgáltatói szegmensbe való belépés korlátjaként értelmezte, míg mások ezt nem tekintették jogszabályi szintü versenykorlátozásnak. A pontszámok átlaga 1,22-ról 1,33-ra nőtt.

Összességében a jogszabályi keretrendszer adott a versenyhez, a belépést a nagykereskedelmi szegmensbe 2013 januárjától a korlátozott (egyszerüsített eljárásban kiadott, csak nagykereskedelemre jogosító) kereskedelmi engedély bevezetésével jelentősen meg is könnyítették, ami hozzájárult a szereplők számának növekedéséhez (MEKH, 2018; MEKH, 2019c). Ez azonban nem jelenik meg a pontozásban, mivel nincs az engedélyezéshez vagy a szereplők számához kapcsolódó kérdés. A kiskereskedelmi szegmensben két jól elkülönülő piac alakult ki: a lakosságot védő árszabályozás gyakorlatilag megszüntette (de nem tiltotta meg) a versenyt az egyetemes szolgáltatói körben, míg a nem egyetemes szolgáltatásban tényleges verseny folyik a fogyasztókért.

\section{Az állami tulajdon szerepe}

2. táblázat $A z$ államitulajdon-mutatók

\begin{tabular}{|l|c|c|c|c|c|c|}
\hline & $\begin{array}{c}\text { Lehetséges } \\
\text { válaszok }\end{array}$ & 2014 & 2015 & 2016 & 2017 & 2018 \\
\hline $\begin{array}{l}\text { A legnagyobb piaci } \\
\text { részesedésủ gázkitermelö/ } \\
\text { gázimportőr-vállalatban } \\
\text { mekkora az állami } \\
\text { tulajdon? }\end{array}$ & $\begin{array}{c}\text { Nincs (0)/ } \\
0-100 \%(3) / \\
100 \%(6)\end{array}$ & 5,06 & 5,06 & 5,06 & 5,06 & 5,06 \\
\hline $\begin{array}{l}\text { A legnagyobb piaci } \\
\text { részesedésủ gázszállító- } \\
\text { vállalatban mekkora az } \\
\text { állami tulajdon? }\end{array}$ & $\begin{array}{c}\text { Nincs (0)/ } \\
0-100 \%(3) / \\
100 \%(6)\end{array}$ & 2,78 & 2,78 & 2,78 & 2,78 & 2,78 \\
\hline $\begin{array}{l}\text { A legnagyobb piaci } \\
\text { részesedésű gázelosztó- } \\
\text { vállalatban mekkora az } \\
\text { állami tulajdon? }\end{array}$ & $\begin{array}{c}\text { Nincs (0)/ } \\
0-100 \%(3) / \\
100 \%(6)\end{array}$ & 1,33 & 1,33 & 2,67 & 3,17 & 3,17 \\
\hline
\end{tabular}

Az állami tulajdon vizsgálatakor az ETCR első kérdése a források tekintetében az állami tulajdonú cégek részesedését vizsgálja a kitermelés és az import esetében. Megállapítható, hogy a kitermelés esetében a legnagyobb részesedés a MOLé, mely többségében magántulajdonban van. Az import legnagyobb hányada az MVM kezében van, mely 100\%-ban állami tulajdonú. A kérdésre adott átlagpontszám 2014 óta nem változott, $(5,06)$ és összességében erős állami tulajdonosi részesedést mutat, mivel a forrásszerkezet $88 \%$-át kivetö import a meghatározó Magyarországon (MEKH, 2019c) (2. táblázat).

A második kérdés a gázszállító hálózat állami tulajdoni részesedésére vonatkozik. Magyarországon 2015 óta két társaság rendelkezik szállítási rendszerüzemeltetői engedéllyel. A szlovák-magyar határkeresztező gázvezetéket üzemeltető Magyar Gáz Tranzit teljes állami kontroll alatt van, a tulajdonosi jogokat - kifejezetten a szétválasztási szabályoknak való megfelelés érdekében - a Belügyminisztérium gyakorolja. A gázhálózat meghatározó részét a Földgázszállító Zrt. (FGSZ) üzemelteti ITO modell alapján, azaz vertikálisan integrált vállalatként (Vince, 2012). Az FGSZ a MOL 100\%os leányvállalata, és nagyobb részben magántulajdonú. Kormányokon átívelő konszenzus figyelhető meg a gázszállító hálózattal kapcsolatban. A szállítóvezeték vonatkozásában az állami tulajdon fontossága az egész időszakon keresztül töretlenül fennállt, az ez irányú külföldi befolyásszerzés esetén az országgyülés összezárt és akár új törvényt is kész volt alkotni, hogy a kontrollt megőrizze (lex MOL) ${ }^{\mathrm{iii}}$. Az energia, de különösen a gázszállító vezetékekkel kapcsolatban a stratégiai megfontolások világszerte gyakran vezetnek a külföldi tulajdonszerzés korlátozásához, sok esetben az állami kontroll megőrzését biztosító jogszabályokon keresztül (milieau, E\&ALaw, 2018). Összességében a pontszám $(2,78)$ a teljes időszakot tekintve közepes mértékü állami kontrollt mutat.

A harmadik kérdés az elosztóhálózatokban megjelenő állami tulajdon mértékét vizsgálja. Az utóbbi években ebben a szegmensben történt a legnagyobb változás. A privatizációkor ugyanis a FÖGÁZ kivételével (ahol továbbra is a Fővárosi Önkormányzat volt a többségi tulajdonos) mind az 5 nagy regionális szolgáltató külföldi tulajdonba (RWE, 
ENI, E.ON) került (Mihályi, 2010; Horánszky, 2006; Vince, 2008). A 2010-es kormányváltás után azonban a nagyobb állami szerepvállalás miatt az állam fokozatosan vásárolta vissza az NKM-en keresztül az egyetemes szolgáltatási, kereskedelmi, és ahol sikerült megegyezni, ott az elosztóhálózati tulajdont is. 2017 júniusában a FÖGÁZ, 2017 decemberében az ÉGÁZ-DÉGÁZ került így magyar állami tulajdonba. Az ENI is eladta a TIGÁZ elosztóhálózatát, itt azonban magyar piaci szereplö, a MET lett az új tulajdonos. A korábban E.ON-tulajdonba került területek (Dél-Dunántúl és Közép-Dunántúl) esetében a cikk írásáig nem történt tulajdonosváltás. Összességében tehát bár növekedett az állami tulajdon az elosztóhálózatokban, a társaságok nagyobb része (mind vezetékhossz, mind ellátási terület nagysága alapján) magántulajdonban maradt. A pontszám a 2014-es 1,33-ról 2018-ra 3,17-re nőtt.

\section{Vertikális integráció}

3. táblázat A vertikális integráció mutatói

\begin{tabular}{|l|l|l|l|l|l|l|}
\hline & \multicolumn{1}{|c|}{$\begin{array}{c}\text { Lehetséges } \\
\text { válaszok }\end{array}$} & 2014 & 2015 & 2016 & 2017 & 2018 \\
\hline $\begin{array}{l}\text { Mekkora a verti- } \\
\text { kális integráció } \\
\text { a gázkitermelö/ } \\
\text { importör és } \\
\text { a szektor más szeg- } \\
\text { mensei között? }\end{array}$ & $\begin{array}{l}\text { Tulajdonosi } \\
\text { szétválasztás (0) / } \\
\text { Jogi/számviteli } \\
\text { szétválasztás (3) } \\
\text { Nincs } \\
\text { szétválasztás (6) }\end{array}$ & 2,39 & 2,50 & 2,50 & 3,61 & 3,61 \\
\hline $\begin{array}{l}\text { Mekkora a verti- } \\
\text { kális integráció a } \\
\text { gázszolgáltató és a } \\
\text { szektor más szeg- } \\
\text { mensei között? }\end{array}$ & $\begin{array}{l}\text { Tulajdonosi } \\
\text { szétválasztás (0)/ } \\
\text { Jogi/számviteli } \\
\text { szétválasztás (3) } \\
\text { Nincs } \\
\text { szétválasztás (6) }\end{array}$ & 3,00 & 3,00 & 3,22 & 3,83 & 3,83 \\
\hline $\begin{array}{l}\text { Elkülönül-e a } \\
\text { gázszolgáltatás az } \\
\text { elosztástól? }\end{array}$ & $\begin{array}{l}\text { Tulajdonosi } \\
\text { szétválasztás (0)/ } \\
\text { Jogi/számviteli } \\
\text { szétválasztás (3) } \\
\text { Nincs } \\
\text { szétválasztás (6) }\end{array}$ & 3,00 & 3,00 & 3,00 & 3,00 & 3,11 \\
\hline
\end{tabular}

A vertikális integráció kérdésének vizsgálatakor az ETCR azt méri, hogy az értéklánc különböző elemei mennyire különülnek el (tulajdonosi/jogi/számviteli alapon) az infrastruktúra üzemeltetéstől. Mint azt korábban bemutattuk, a magyar gázszállító rendszer tulajdonosa az FGSZ, mely $100 \%$-ban a MOL tulajdona. A MOL a magyar gázkitermelési piacon a legnagyobb szereplö, így a kitermelés és szállítás esetében nem beszélhetünk tulajdonosi szétválasztásról (3. táblázat).

Az index növekedését minden szegmensben az a jelentős változás indokolja, hogy az állam az MVM-csoporton keresztül növelte tulajdonosi szerepét, így a fokozódó koncentráció minden szegmensben együttjárt a vertikális integráció növekedésével. Mint azt korábban már részletesen ismertettük, mára a kitermelés kivételével az MVM - mely 2013 előtt jóformán kizárólag az árampiacon volt jelen - gyakorlatilag a földgázpiac minden szegmensében jelentős szereplő lett. Az elosztóhálózatok esetében ugyanakkor a szétválasztás erősödött azokban a régiókban, ahol az elosztóhálózat nem került az NKM tulajdonába, de az egyetemes szolgáltatás igen (TIGÁZ, Dél-Dunántúl, Közép-Dunántúl esetében). Érdekes módon ez a pontozásban nem tükröződik.
A tulajdonosi szétválasztás a verseny számára legkritikusabb területen, a szállítórendszer esetében azonban fennmaradt, mivel az FGSZ nem az MVM tulajdonában van.

4. táblázat A piacszerkezet mutatói

\begin{tabular}{|l|l|l|l|l|l|l|}
\hline & $\begin{array}{l}\text { Lehetséges } \\
\text { válaszok }\end{array}$ & 2014 & 2015 & 2016 & 2017 & 2018 \\
\hline $\begin{array}{l}\text { Mekkora a legnagyobb } \\
\text { gázkitermelö/importőr } \\
\text { cég piaci részesedése? }\end{array}$ & $\begin{array}{l}50 \% \text { alatt (0) } \\
50-90 \%(3) \\
90 \% \text { felett (6) }\end{array}$ & 3,00 & 3,00 & 3,11 & 2,28 & 2,28 \\
\hline $\begin{array}{l}\text { Mekkora a legnagyobb } \\
\text { gázszállító cég piaci } \\
\text { részesedése? }\end{array}$ & $\begin{array}{l}50 \% \text { alatt (0) } \\
50-90 \%(3) \\
90 \% \text { felett (6) }\end{array}$ & 4,67 & 4,67 & 4,67 & 4,67 & 4,67 \\
\hline $\begin{array}{l}\text { Mekkora a legnagyobb } \\
\text { gázszolgáltató cég } \\
\text { piaci részesedése? }\end{array}$ & $\begin{array}{l}50 \% \text { alatt (0) } \\
50-90 \%(3) \\
90 \% \text { felett (6) }\end{array}$ & 0,11 & 0,22 & 1,17 & 1,67 & 2,17 \\
\hline
\end{tabular}

\section{Piacszerkezet}

A piacszerkezettel kapcsolatos első kérdés, hogy mekkora a részesedése a legnagyobb kitermelö és a legnagyobb importáló vállalatnak. Magyarországon a források döntő része importból származik, a hazai kitermelés 1,6 milliárd $\mathrm{m}^{3}$ /év körüli értéken stagnál az utóbbi években. A hazai kitermelés domináns szereplöje a MOL, ugyanakkor 2010 óta a koncessziós pályázatok lehetőséget teremtettek arra, hogy új belépők is transzparens feltételek mellett versenyző ajánlatokat tehessenek magyarországi kutatásra és mezőt fejleszthessenek. Ezen pozitív fejlemények révén a kisebb termelők száma és kitermelése is növekedésnek indult. Az új mezőkért egyre nagyobb a verseny, ennek köszönhetően a bányajáradékból származó bevétel arányosan nagyobb az új koncessziós kitermelésből (Zelei, 2018). Ezen a téren tehát nőtt a verseny.

Az import tekintetében az 1990-ben kötött hosszú távú szerződés mindenkori tulajdonosa a domináns szereplő. Ez a szereplő 2006-ig a MOL, azt követően 2013-ig az E.ON, majd az MVM lett. Az MVM importban történő részesedésének utóbbi két évben való csökkenése ugyanakkor nem az MVM importjának csökkenésével magyarázható, hanem annak a fejleménynek köszönhetö, hogy a magyar szállítóhálózaton az utóbbi években jelentősen megnőtt az átszállítás volumene, így arányaiban csökkent az MVM importban való részesedése a megnövekedett tranzitszállítások miatt (MEKH, 2019c). A nagykereskedelmi szegmens mindazonáltal ezek alapján versenyzőinek tekinthető. A jelentősen megnövekedett tranzitszállítási tevékenység miatt ez az egyetlen almutató, amely javulást mutat, a 2014-es 3,0-ról 2,28-ra csökkent az értéke.

A második kérdés arra vonatkozik, hogy mekkora a szállítói hálózatban a legnagyobb vállalat részesedése. Ennek a mutatónak a kiszámítása a magyar szabályozási rendszerben nem értelmezhető, mivel a szállítás szabályozott monopoltevékenység. Az összehasonlíthatóság kedvéért - mivel a kompozit mutató kiszámításában korábban is benne volt - a számított értéket mi is szerepeltetjük.

A kiskereskedelmi piaci részesedésben láthatjuk a legnagyobb változást az utóbbi években, mivel az egyetemes szolgáltatási piacon az állam fokozatosan kivásárolta a külföldi tulajdonosokat, így amint az a MEKH országgyülési beszámolójából is kiolvasható, a legnagyobb 
szereplő mára az MVM tulajdonában lévő NKM lett. A pontozás tehát a 2013-14 időszakban 0,11 (a legnagyobb részesedés 50\% alatti) 2016-tól 1 fölé kerül, majd 2,17-re emelkedik (4. ábra).

4. ábra Befektetői csoportok részesedésének változása a kiskereskedelmi piacon értékesített földgáz mennyisége alapján (2005-2018. november)

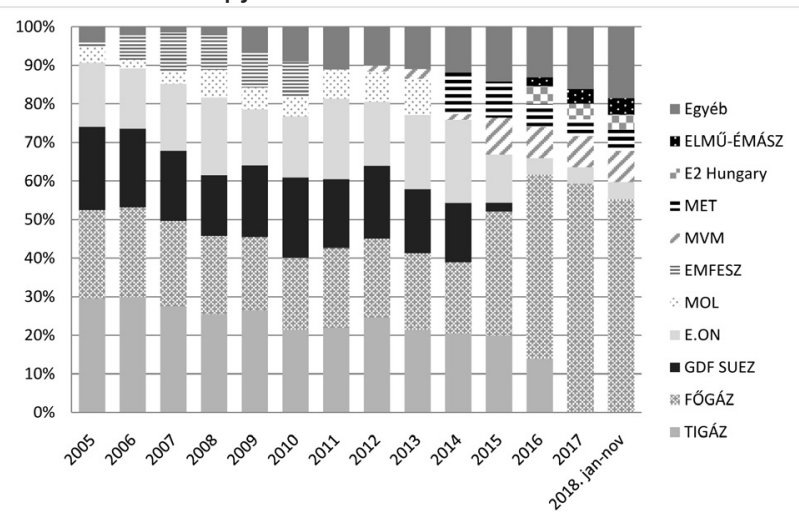

Forrás: saját ábra MEKH (2019c) alapján

Bár az ETCR-mutatónak nem része, az egyes szegmensekben a legnagyobb piaci szereplök vizsgálatán túl érdemes megvizsgálni a Hirschmann-Herfindahl - index alakulását is, amely nem csupán a legnagyobb, hanem az összes piaci szereplő részesedését figyelembe veszi (5. táblázat).

5. táblázat A piaci koncentráció alakulása a gázpiac szegmenseiben, 2014-2017

\begin{tabular}{|l|c|c|c|c|}
\hline HHI-index & 2014 & 2015 & 2016 & 2017 \\
\hline $\begin{array}{l}\text { Nagykereskedelmi } \\
\text { értékesítés }\end{array}$ & 4813 & 5677 & 4839 & 2501 \\
\hline $\begin{array}{l}\text { Lakossági } \\
\text { végfelhasználóknak } \\
\text { történő értékesítés }\end{array}$ & 2569 & 2628 & 4202 & 10000 \\
\hline $\begin{array}{l}\text { Nem lakossági } \\
\text { végfelhasználóknak } \\
\text { történő értékesítés }\end{array}$ & 1096 & 1078 & 1205 & 1170 \\
\hline
\end{tabular}

Forrás: MEKH \& FGSZ (2018) adatai alapján

Látható, hogy bár a HHI-index értékének csökkenése is jelzi a nagykereskedelmi piacon 2017 óta élénkülő versenyt, ez a szegmens az index értéke alapján a konvenciók szerint továbbra is koncentráltnak tekinthető. Ugyanakkor a kiskereskedelmi piac nem lakossági szegmensében az index értéke egyetlen évben sem megy 1500 fölé, vagyis ez a szegmens versenyzőinek tekinthetö. A lakossági szegmens esetében a HHI-index bár meghatározható, az értelmezésével érdemes óvatosnak lenni. A 10.000-es érték jól jelzi az egyetemes szolgáltatók egy kézbe kerülését, azonban a korábbi, alacsonyabb értékek sem jelentik igazán a verseny jelenlétét, hiszen jellemzően regionális monopóliumokról volt szó.

\section{ETCR összefoglalás}

Az általunk vizsgált évekre vonatkozóan a kérdőíves válaszok alapján becsült összesített földgázpiaci ETCRértékek a 6. táblázatban szerepelnek összefoglalóan.
6. táblázat Az ETCR becsült értékei, Magyarország, gázpiac

\begin{tabular}{|l|c|c|c|c|}
\hline & REKK becslés & Szabályozó & Minisztérium & Átlag* \\
\hline 2014 & 1,94 & 2,33 & 2,62 & 2,27 \\
\hline 2015 & 1,94 & 2,48 & 2,62 & 2,32 \\
\hline 2016 & 2,06 & 2,82 & 2,87 & 2,56 \\
\hline 2017 & 2,68 & 2,80 & 2,87 & 2,78 \\
\hline 2018 & 2,80 & 2,82 & 2,87 & 2,83 \\
\hline
\end{tabular}

*Átlag: az előző három oszlop egyszerű számtani átlaga

Az ETCR-gázindikátor OECD által becsült múltbeli értékeit, és a 2014-18-as időszakra vonatkozó általunk becsült értékeit mutatja az 5. ábra.

\section{5. ábra Az ETCR gázindex becsült értékei Magyarország vonatkozásában}

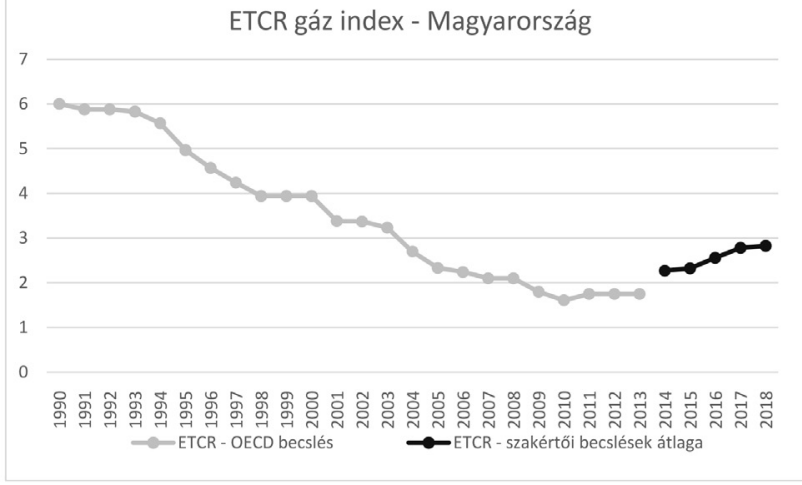

Forrás: (OECD, 2019) \& REKK becslés

Látható, hogy míg az index értéke 2010-ig folyamatosan csökken, majd azt követően 2013-ig állandónak tekinthető, 2014-től növekedésnek indul, és folyamatosan emelkedik. Ennek oka az állami tulajdon, és ezáltal a vertikális integráció növekedése, illetve a kiskereskedelemben legnagyobb vállalat részesedésének a növekedése.

Ez alapján a szabályozási indikátor alapján tehát az a következtetés vonható le, hogy Magyarországon 2010-et követően kevésbé versenybaráttá vált a szabályozás a földgázpiacon, melynek oka elsősorban az állami tulajdonosi szerepvállalás és ezzel együtt a vertikális integráció növekedése.

\section{Az MPI-index}

Azt, hogy egy piac megfelelően müködik-e, a szabályozó hatóságokon, elemzőkön és szakértőkön kívül a fogyasztók is meg tudják ítélni a saját vásárlási tapasztalataikon keresztül. A fogyasztók elvárásai egy piac müködésével szemben elsősorban arra vonatkoznak, hogy a termékeket/szolgáltatásokat az elvárásaiknak megfelelő minőségben és áron kapják-e meg. Az elégedettségüket ugyanakkor befolyásolja az is, hogy az esetleges minőségi kifogásaikat, fogyasztóvédelmi panaszaikat mennyire tudják érvényesíteni, mennyire bíznak abban az intézményrendszerben, amely körülveszi öket.

Ezt felismerve az Európai Bizottság azon keresztül is tájékozódik a piacok működéséről, hogy rendszeresen vizsgálja a fogyasztók elégedettségét 40 termék és szolgáltatás piacán, köztük a földgázpiacon is. 
Az Európai Unió mind a 28 tagállamában, valamint Norvégiában is telefonos lekérdezéssel gyüjtik a lakossági véleményeket a piacok müködéséről. Minden ország minden vizsgálatba bevont piaci szegmensében 500 olyan válaszadót keresnek meg, akinek tényleges vásárlási tapasztalata volt az elmúlt időszakban az adott termékkel/ szolgáltatással kapcsolatban.

A lekérdezés célja, hogy statisztikailag megbízható, összehasonlítható adatok álljanak rendelkezésre a tagállamok piacairól, ami alapján kiszürhető, hogy mely piacok működésével elégedetlenek a fogyasztók.

Az így begyüjtött adatok képezik az alapját az MPI (Market Performance Indicator) mutatónak, melyet az Európai Bizottság 2010 óta alkalmaz a piacok működésének mérésére. Jelenleg hat felvétel adatai állnak rendelkezésre, de tekintettel a módszertan változásaira (elsősorban a súlyozással kapcsolatban), jelen cikkben a 2013-as, 2015-ös és 2017-es évek adataira fogunk szorítkozni.

Az indikátor komponensei a következők: összehasonlíthatóság, bizalom, problémák és megkárosítás, várakozások és választási lehetőség. A kérdőív összeállítása során figyelemmel voltak arra, hogy tartalmazzon attitüdbeli (bizalom, várakozások) és viselkedési dimenziókat is (panaszok, szolgáltatóváltás).

A válaszadók 0-10 pont között adnak pontokat, ahol a nagyobb pontszám mindig a nagyobb elégedettséget mutatja. Az egyes komponensekre adott válaszok pontjait súlyozva veszik figyelembe. Az alkalmazott súlyokat is maga a válaszadó határozza meg, jelölve, hogy szerinte melyik kérdéskör a fontosabb (European Commission, 2018a). Az MPI-indikátor alapján elvégezhető az időszakok, a termékek, illetve szolgáltatások és az országok öszszehasonlítása.

Az MPI-indikátort minden országra és minden termékcsoportra/szolgáltatásra is ki lehet számolni, de akár az EU28-ra is meghatározható egy MPI az összes piacra vonatkozóan, ami összevethető az előző évek felméréseivel. Általánosságban az a tapasztalat, hogy az egész Európai Unióra vonatkoztatva megfigyelhető a mutatószám javulása, azaz a fogyasztók elégedettsége növekszik a mutatószám alapján (European Commission, 2018a).

$\mathrm{Az}$ azonban igen meglepő, hogy az MPI-indikátor alapján Magyarország piaci teljesítménye a termékek és a szolgáltatások területén is a legjobb helyen szerepel a fogyasztói vélemények alapján az Európai Unió országai között, azaz a magyar válaszadók értékelték a legmagasabbra a termékek és a szolgáltatások színvonalát. A 15 termékcsoport közül 14-ben legmagasabb és egyben második legmagasabb, míg a 25 szolgáltatási csoportból 19-ben a legmagasabb, kettőben a második és egyben a harmadik legmagasabb pontszámot a magyar válaszadók adták. A magyar fogyasztók összességében mind a termékek $(+6,0)$, mind a szolgáltatások $(+6,6)$ terén jelentősen növelték a pontszámukat 2015-ről 2017-re, és magasan az EU-átlag fölött elégedettek a piac müködésével (European Commission, 2018).

Ha csak a magyar eredményekre fókuszálunk, a szolgáltatások piacát a villamosenergia-szolgáltatás magasan vezeti $(+93,8)$, de a földgázpiaci MPI is átlag fölötti
(+88,7). 2013-ról 2017-re mindkét energiaszolgáltatás esetében százas skálán 23 pontot javult a mutató értéke Magyarországon. Ha ehhez a két szegmenshez még hozzátesszük, hogy a harmadik olyan szolgáltatási piac, ahol a fogyasztói elégedettség 20 pont fölötti javulást eredményezett Magyarországon a jelzálogpiaci szolgáltatás $(+29,6)$ volt (European Commission, 2018c), akkor az állami beavatkozások kulcsterületeit kapjuk. Feltehetőleg a rezsicsökkentés és a lakáshiteleseket célzó állami programok hatására a magyar fogyasztók szemében mind a bizalom (tudniillik, hogy mennyire bízik abban, hogy a fogyasztói érdekek védelme hatékonyan müködik), mind az összehasonlíthatóság (hogy a kínált szolgáltatás más eladókhoz képest milyen árú) szempontjából nagyot nőtt a villamosenergia- és a gázszolgáltatások minősége. Mivel a magyar piacon nem a versenyző lakossági ajánlatok jelentik az összehasonlíthatóság alapját, valószínüsíthető, hogy a kormány által rendszeresen kommunikált rezsicsökkentési eredmény érte el ezt a hatást, melynek alapja a MEKH honlapján havonta megjelenő, a különböző európai fővárosokban fizetendő villany- és gázdíjakat összehasonlító elemzés (MEKH, 2019a).

Az nem magyar sajátosság, hogy a földgázszolgáltatás piacán a váltás lehetőségét és az összehasonlítható ajánlatok meglétét nem értékelik fontosnak a fogyasztók, ez általánosan igaz, ezeknek a paramétereknek adták a legkisebb súlyt a válaszadók európai szinten is (European Commission, 2018b).

\section{6. ábra A gázpiaci szolgáltatási MPI az Európai Unió} országaiban, 2013,2015,2017

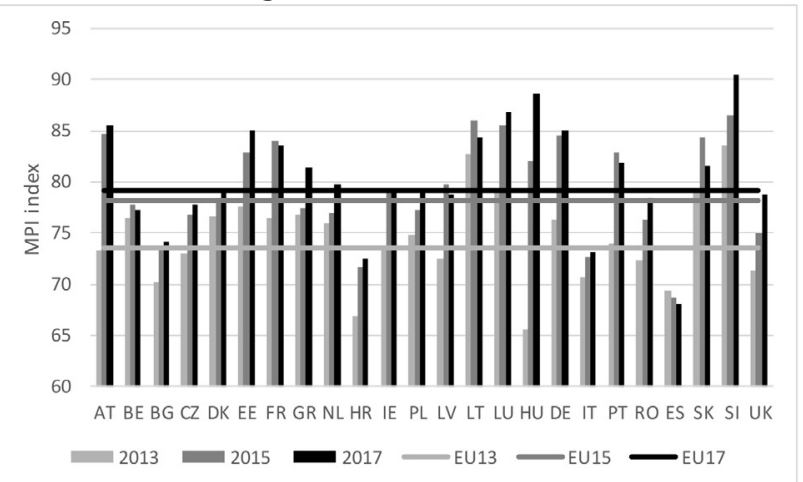

Adatok forrása: Consumer Markets Scoreboard

A 6. ábrán a földgázpiaci MPI-index látható a 2013, 2015 és 2017-es évekre. Míg 2013-ban a magyar válaszadók jóval az EU-átlag alatti pontszámokkal értékelték a földgázpiac múködését, ez már 2015-re is átlag fölöttire változott, majd 2017-re a második legmagasabb pontszámot kapta a szlovének után.

Feltételezhetö, hogy a fogyasztók piacról alkotott véleménye negatív kapcsolatban van az árakkal. Ennek a kapcsolatnak a vizsgálatára az MPI-pontszámok és a HICP-index (Harmonised Index for Consumer Prices) korrelációját vizsgálva bebizonyosodott, hogy minél magasabbak az árak, annál rosszabb véleménnyel vannak a fogyasztók az adott piacról (European Commission, 2018a). 


\section{A földgázárak alakulásának a vizsgálata}

A nagykereskedelmi verseny állapotát jól mutatja, hogy a Magyarországra érvényes földgázárak hogyan alakultak a múltban és milyen viszonyban álltak a régióban érvényes többi meghatározó gázárral. A kiskereskedelemre vonatkozóan a fogyasztói árszabályozás jóságát mérhetjük azzal is, hogy mennyire képes a nagykereskedelmi árak alakulását a fogyasztói árakban érvényesíteni: bizonyos késleltetéssel vagy tompítással a szabályozott gázáraknak le kell(ene) követniük a nagykereskedelmi piacokon megfigyelhetó áremelkedéseket vagy áreséseket.

Az európai földgázpiacokat a hosszú távú orosz szerzödéses gáz ára (orosz gáz a német határon) és a leglikvidebb európai tőzsdén, a TTF-en kereskedett gáz ára jellemzi legjobban. A 2006-2014 közötti időszakban a tőzsdei (TTF) árak általában kedvezőbbek voltak a hosszú távon kereskedett gáznál, majd a hosszú távú szerződéses gázár prémiuma lassan eltűnt, elsősorban a szerződés tárgyalások útján történő módosításának köszönhetően. A gazdasági válság hatására visszaeső gázkereslet miatt Európában gázbőség alakult ki, az át nem vett hosszú távú szerződéses mennyiségek megjelentek a tőzsdén és erősen mérsékelték a földgázárakat. A hosszú távú szerződésekben fokozatosan megjelent a tőzsdei indexálás, a kötelező átvételi mennyiségek rugalmasabb kezelése, ez pedig a hosszú távú szerződéses és a tőzsdei árak szorosabb együtt mozgásához vezetett (Kaderják, 2010).

A magyar piacot négy idősorral írjuk le: a földgáz importszerződést kezelő Panrusgaz által közölt éves átlagos szerzödéses gázárral, az Eurostat külkereskedelmi adatbázisa alapján számított orosz import gázárral, illetve az Eurostat által közölt lakossági és ipari gázárral: ami a molekulaárat és a hálózati tételeket tartalmazza, de az adókat és egyéb járulékokat már nem, a molekulaár a végfogyasztói ár 55-70\%-át teszi ki.

A magyar nagykereskedelmi árak a német határon leszállított orosz gázzal szorosan együtt mozogtak 2009-ig, majd a 2009 és 2013 közötti időszakban jelentős mértékben, 3-10 €/ MWh-val meghaladták azt. 2014-től a német és magyar árak különbözete újra eltünt. 2018 végére a hosszú távú szerződéses és a tőzsdei árak újra szétváltak, ezúttal a német határon leszállított hosszú távú szerződéses ár bizonyult kedvezőbbnek.

A magyar lakosság számára érvényes gázár (hálózati tételekkel együtt, de adók és járulékok nélkül) a 2004-2011 időszakon a nagykereskedelmi áralakulásokat tompítva követte le: a szabályozás elismerte az áremelkedéseket (pl. a 2007-2008 vagy a 2010-2011 időszakokat), de például a 20082009-es több mint $10 € / M W h$ árcsökkenés nem érvényesült a lakossági árakban. Ezzel szemben az ipari gázárak erősebben együtt mozogtak a nagykereskedelmi folyamatokkal, például a 2015 utáni olajáresést is lekövették. Ezt a tendenciát a rezsicsökkentés fordította meg, 2013-2014-ben három lépésben csökkentve a lakossági földgáz árát, ami azóta változatlan maradt. A 2015-2017-es években azonban a földgáz ára tovább csökkent, és habár a lakossági fogyasztók a befagyasztott árakkal már nem voltak kitéve a volatilitásnak, a csökkenő gázárak miatti megtakarítást sem érzékelték. Ez úgy történhetett meg, hogy annak ellenére, hogy a lakossági gázárban a szabályozó érvényesítette a nagykereskedelmi árak változását a TTF és a hosszú távú szerződéses gázár indexálása révén, az egyetemes szolgáltatói árrést minden esetben úgy határozta meg, hogy a rezsicsökkentett gázárak változatlanok maradjanak. Következésképpen az egyetemes szolgáltatói árrés a második rezsicsökkentés kezdetekor érvényes (2014. április) $3 \mathrm{Ft} / \mathrm{m} 3$-ről 8,38 Ft/m3-re nőtt (2016. április), azóta 6,-Ft/m3 szinten áll (MEKH, 2019d).

A lakossági gázárak tehát nagyon laza kapcsolatban álltak a mindenkori nagykereskedelmi árakkal: a 2010-es árbefagyasztást megelőzően a szektor szereplői sikeresen érvényesítették költségeiket a szabályozott árakban, míg a rezsicsökkentést követően a befagyasztott árak nem tükrözték a piaci viszonyokat.

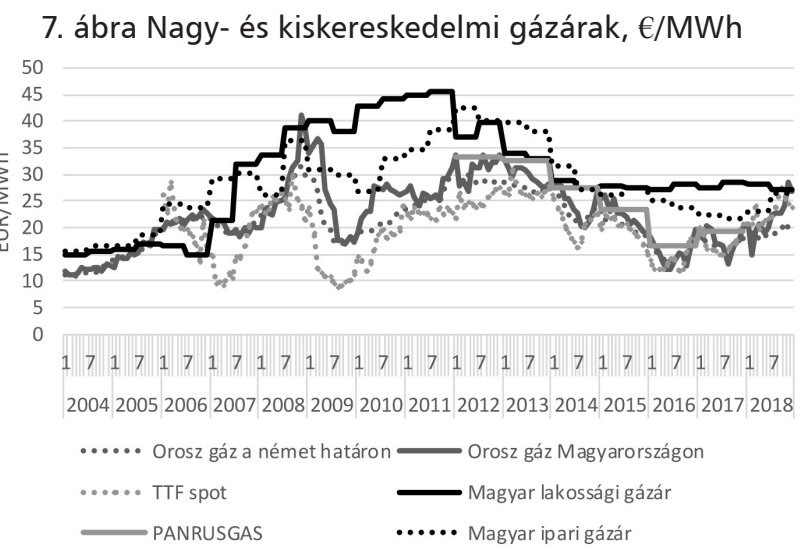

Forrás: PEGAS, Panrusgas, BAFA, Eurostat, MEKH alapján REKK

Magyarországon a 7. ábrán is jól láthatóan voltak időszakok, amikor a hálózati költségeket is tartalmazó lakossági szabályozott árak nem, vagy alig haladták meg a gázmolekula nagykereskedelmi árát (2006-2007; 2012-2013, illetve az ACER adatai szerint 2015 és 2017 is) (ACER, 2018b). A végfogyasztói árak beszerzési költségek alatt tartása kétségtelenül népszerü lépés, de hosszú távon belépési korlátot teremt és megakadályozza a versenyt, gátjává válik a befektetéseknek és az innovációnak. Ott, ahol ez a szabályozás hosszabb időn keresztül fennáll, a fogyasztók nem kapnak megfelelő árjelzést, ami pazarló fogyasztási magatartásra ösztönöz, elmaradnak az energiahatékonysági beruházások is. Ezt a hatást a magyar lakossági fogyasztási adatokon is láthatjuk 2010-15 között (Sebestyén Szép, 2017).

A másik irányba való eltérés, azaz, ha a beszerzési költségek jelentösen alatta vannak a szabályozott áraknak (amire szintén láthatunk példát a 7. ábrán), de nincs verseny a piacon a magas szabályozói kockázat miatt, a vállalati pazarlás ösztönzője lehet, az indokolatlanul magas bevételek megnövelik a szabályozó befolyásolásának kockázatát.

Az ACER megállapítása szerint sok európai országban gyenge a kapcsolat a nagy- és kiskereskedelmi árak között. A nagykereskedelmi árakban bekövetkezö változások gyakran nem köszönnek vissza a kiskereskedelmi árakban, és ezért a nagykereskedelmi árak csökkenése sem jut el a háztartási fogyasztókhoz mindenhol. A korreláció a nagykereskedelmi ár és a kiskereskedelmi ár energiakomponense között az Európai Unióban két országcsoport esetében mutatható ki, különböző okokból. Az egyik csoportban a versenyzői szegmens ajánlatai közvetlenül a nagykereske- 
delmi árakhoz kötik a kiskereskedelmi árakat is. A másik csoportban a szabályozott végfelhasználói árakat használó azon országok vannak, ahol a szabályozás ezt az árat a nagykereskedelmi árakhoz indexálja (ACER, 2018b).

\section{Diszkusszió}

Az, hogy egy földgázpiac mennyire múködik, és a szabályozása mennyire jó, összetett kérdés. Ezt a problémát három különböző szemléletben vizsgáltuk: (i) az ETCR kompozit indexszel a szabályozás vizsgálatára alapozva, (ii) a fogyasztók véleményének kérdőíves mérésére alapuló MPI kompozit indexszel, illetve (iii) a nagy- és kiskereskedelmi piaci árak együttmozgásának vizsgálatával.

A versenypiaci modellben, melyet az Európai Unió és annak tagjaként Magyarország is implementált, bizonyos szabályozási feltételek elengedhetetlenek ahhoz, hogy a hálózatos szolgáltatások piacán, mint amilyen a földgázpiac, bármiféle verseny megvalósulhasson. Ilyen alapfeltétel a tevékenységek szétválasztása és az infrastruktúrához való szabályozott harmadik feles hozzáférés biztosítása. A piaci struktúra és a tulajdonosi szerkezet (állami vagy magántulajdon) is hatással lehet a versenyre. Ezen paramétereket összesíti az ETCR-index, melynek segítségével áttekintve a magyar földgázpiaci liberalizáció történetét azt láthatjuk, hogy az 1990-es kiinduló állapotból, mely egy vertikálisan integrált állami tulajdonú monopólium volt, 2010-ig egyértelmű elmozdulás történt a versenypiaci modell fokozatos megvalósítására. Létrejött egy sokszereplős, jórészt külföldi cégek tulajdonában álló földgázpiac. A 2010-es évet követően jelentős változás állt be a földgázpiacra vonatkozó állami stratégiában. Az állami beavatkozás egyrészt az árszabályozásban - a lakossági (egyetemes szolgáltatási) körben először az árak befagyasztásában, majd több körben az árak csökkentésében -, másrészt az állami tulajdon felvásárlásokon keresztüli jelentős növelésében nyilvánult meg. Ennek következtében bizonyos piaci szegmensekben (például a lakossági gázszolgáltatásban) egyetlen, állami tulajdonú szereplő maradt a piacon, ezáltal a fogyasztók szolgáltatóváltási lehetősége gyakorlatilag megszünt. A vertikális integráció is újra erősödni kezdett, mivel a domináns állami tulajdonú szereplő (MVM) a gázkereskedelmi tevékenység mellett mind a tárolói piacon, mind az elosztóhálózat terén rohamos felvásárlásokba kezdett. E tényezők miatt az ETCR-mutató alapján a versenypiaci környezet 2010 után először stagnált, majd romlásnak indult Magyarországon. Fontos leszögezni azonban, hogy a szabadpiaci szegmensben továbbra is sokszereplős verseny van, és az infrastruktúrához való szabályozott harmadik feles hozzáférés és a piacra való belépés de jure biztosított.

A versenypiaci szabályozást értékelő ETCR-mutató romlása ugyanakkor nincs összhangban azzal, hogy a magyar lakossági fogyasztók hogyan ítélik meg a szektorban a szolgáltatást. A földgázpiaci szolgáltatással való elégedettségük az MPI-mutató által vizsgált komponensek alapján (bizalom, várakozás, szolgáltatóváltás lehetősége, összehasonlíthatóság) összességében 2013 után látványosan javult.

Az elégedettség legnagyobb forrása vélhetően a (szabá- lyozott) végfogyasztói ár csökkenése. Ez a bizalomra olyan módon hathatott (és nyilvánult meg az MPI-index javulásában), hogy a fogyasztó a rezsicsökkentésen keresztül nagyon erős jelzést kapott arra, hogy a politika a fogyasztói érdekeket érvényesíti a vállalati érdekekkel szemben.

Ugyanakkor, mint arra az árak vizsgálata során rámutattunk, az egyetemes szolgáltatói végfogyasztói árakba történő politikai beavatkozás egyirányú és kampányszerü volt, még ha indokolt is. A nagykereskedelmi árak további csökkenését majd időszakos emelkedését ugyanis nem követte az egyetemes szolgáltatói végfogyasztói árak változása. Ennek következtében a piaci árak folyamatos változásának függvényében hol a fogyasztók érezhetik úgy, hogy megkárosítják őket, hiszen nem részesülnek a nagykereskedelmi árak csökkenéséből, hol az állami tulajdonú gázkereskedő válhat - az árak számára kedvezőtlen alakulása során - a veszteségek legfőbb finanszírozójává. Az eltérés egyik irányba sem kedvező, és hosszú távon nehezen fenntartható. A szabályozó függetlensége Magyarországon az egyetemes szolgáltatói árszabályozásban kétségkívül korlátozott. A rezsicsökkentés politikai és nem szabályozói döntés volt. Az intézkedés jelentős politikai nyereséget hozott, ami az MPI-index javulásában is jól tükröződik. A politikai környezetről sokat elmond, hogy a 2013-as év szavának a Magyar Nyelvstratégiai Kutatócsoport és a Magyar Nyelvi Szolgáltató Iroda felmérése a „rezsicsökkentést” választotta.

Összefoglalóan megállapíthatjuk, hogy mint sok más helyen a világban, Magyarországon is zajlott egy szabályozói kísérlet arra vonatkozóan, hogy a szabályozott piaci versennyel a fogyasztói jólét és a hatékonyság növelésének kettős célja megvalósuljon.

A hatékonyság a piacnyitással a vállalati müködésben javult, és a szabadpiaci szegmensben tényleges és hatékony verseny zajlik. Ugyanakkor a nagykereskedelmi és a lakossági árak tartós elszakadása 2008-2011 között arról árulkodik, hogy az egyetemes szolgáltatási szegmensben a versenypiac nem müködött hatékonyan.

Az iparág jelentős részének állami kézbe kerülésével megnőtt annak a veszélye, hogy a vállalati müködésben háttérbe szorul a hatékonyság. Ugyanakkor mivel a szabályozás nem növelte a piaci belépési korlátokat és a szállítóvezetékhez való szabályozott harmadik feles hozzáférés is garantált, a verseny lehetősége elvileg fegyelmező erővel bírhat az immár domináns piaci erőfölényre szert tett állami szolgáltatóra. Ennek ellentmond azonban a külföldi magántulajdonú szereplők fokozatos kivonulása a magyar földgázpiac különböző szegmenseiből. A potenciális új belépők bizalma erösen csökkent a magyar szabályozással kapcsolatban. Mivel tehát versenyre az egyetemes szolgáltató szegmensben a közeljövőben nem számíthatunk, véleményünk szerint a probléma leghatékonyabb megoldása, ha a szabályozás a nagykereskedelmi árak változását bizonyos tompítással, transzparens módon beépíti a kiskereskedelmi szabályozott árakba. A jól müködő szabadpiaci szegmensben pedig a verseny feltételeinek megőrzésével biztosítja a piac hatékony müködését. 


\section{Felhasznált irodalom:}

ACER (2017). Annual Report on Contractual Congestion at Interconnection Points .

ACER (2018a). ACER Market Monitoring Report 2017 Gas Wholesale Markets Volume.

ACER (2018b). ACER Market Monitoring Report 2017 Electricity and Gas Retail Markets Volume.

Bastianin, A., Castelnovo, P., \& Florio, M. (2018). Evaluating regulatory reform of network industries: a survey of empirical models based on categorical proxies. Utilities Policy, 55, 115-128. https://doi.org/10.1016/j.jup.2018.09.012

Beöthy, Á., Takácsné Tóth, B., Kaderják, P., \& Kotek, P. (2016). Megérte megépíteni a szlovák magyar földgázvezetéket? REKK Policy Brief 2016/06.

Brandão, A., Pinho, J., Resende, J., Sarmento, P., \& Soares, I. (2016). Welfare effects of unbundling under different regulatory regimes in natural gas markets. Portuguese Economic Journal, 15(2), 99-127. https:// doi.org/10.1007/s10258-016-0114-9

Brau, R. D. (2010). EU gas industry reforms and consumers' prices. The Energy Journal, 31(4), 167-182. https://doi. org/10.5547/ISSN0195-6574-EJ-Vol31-No4-8

Ceriani, L., Doronzo, R., \& Florio, M. (2009). Privatization, unbundling, and liberalization of network industries: a discussion of the dominant policy paradigm in the EU. Departmental Working Papers 2009-09, Department of Economics, Management.

Conway, P., \& Nicoletti, G. (2006). Product Market Regulation in the Non-Manufacturing. OECD Economics Department Working Papers No. 530. https://doi. org/10.1787/362886816127

European Commission (2014). Country Report Hungary. https://ec.europa.eu/energy/sites/ener/files/documents/2014_countryreports_hungary.pdf.

European Commission (2014). Progress towards completing the Internal Energy Market - Country Reports. COMMISSION STAFF WORKING DOCUMENT. Forrás: https://eur-lex.europa.eu/legal-content/EN/ $\mathrm{TXT} / \mathrm{PDF} /$ ?uri=CELEX:52014SC0311\&qid $=15583578$ 09501\& from $=\mathrm{EN}$

European Commission (2018). 2018 Consumer Markets Scoreboard. https://doi.org/10.2838/25750

European Commission (2018a). Monitoring Consumers Markets in the European Union in 2017 - Part 1. https://doi.org/10.2818/597528

European Commission (2018b). Monitoring Consumer Markets in the European Union in 2017 - Part 2.

European Commission (2018c). Monitoring Consumer Markets in the European Union in 2017 - Part 3.

Farkas, Z. (2014). Hatósági árszabályozás a magyar földgáziparban. In O. Fazekas (szerk.), A magyar földgázszektor müködése és szabályozása (pp. 383-489). Budapest: CompLex.

Fazekas, O. (2014). A magyar földgázszektor müködése és szabályozása (I. kötet). Budapest,: CompLex.

Felsmann, B. (2018). Firm Performance Under Institutional Constraints - Strategic adaptation and corporate co-evolution in the Hungarian energy retail sector. PhD Dissertation.
Florio, M. (2014). Energy Reforms and Consumer Prices in the EU over twenty Years. Economics of Energy \& Environmental Policy(Vol.3. No.1.), 37-52. https://doi. org/10.5547/2160-5890.3.1.mflo

Growitsch, C., \& Stronzik, M. (2014). Ownership unbundling of natural gas transmissionnetworks: empirical evidence. Journal of Regulatory Economics, 46(2), 207-225. https://doi.org/10.1007/s11149-014-9252-0

Herweg, N., Wurster, S., \& Dümig, K. (2018). The European Natural Gas Market Reforms Revisited: Differentiating between Regulatory Output and Outcome. Social Sciences, 7(4). https://doi.org/10.3390/socsci7040057

Horánszky, B. (2006). Vállalati struktúrák változásai a földgázellátó szektorban. Vezetéstudomány, 37(4), 48-54.

IEA (2017). Energy Policies of IEA Countries - Hungary 2017.

IPA (2015). Ranking the Competitiveness of Retail Electricity and Gas Markets: A proposed methodology.

Kaderják, P. (2010). Középtávú gázpiaci kilátások. REKK jelentés az energiapiacokról 2010/2, 6-8.

Kotek, P., \& Szabó, L. (2014). A második rezsicsökkentés. REKK jelentés az energiapiacokról 2014/1.

Kotek, P., \& Takácsné Tóth, B. (2017). A március 6-i PRISMA kapacitásaukciók rövid értékelése. REKK jelentés az energiapiacokról 2017/2-3, 11-16.

Kotek, P., Szajkó, G., Mészégetőné Keszthelyi, A., \& Szabó, L. (2013). Vihar a rezsiben. REKK jelentés az energiapiacokról 2013/1.

MEKH (2014). Országgyülési beszámoló 2013.

MEKH (2018). Országgyülési beszámoló 2017.

MEKH (2019a). A lakossági villamos energia és földgázárak nemzetközi összehasonlító vizsgálata.

MEKH (2019b). A TAR NC 29. cikke által előirt közzétételi kötelezettség teljesitése - 2019. Forrás: http://mekh. hu/a-tar-nc-29-cikke-altal-eloirt-kozzeteteli-kotelezettseg-teljesitese-2019

MEKH (2019c). Országgyülési beszámoló 2018.

MEKH (2019d). Földgázpiaci egyetemes szolgáltatáshoz kapcsolódó árképzés. Forrás: http://mekh.hu/foldgazpiaci-egyetemes-szolgaltatashoz-kapcsolodo-arkepzes

MEKH, \& FGSZ (2018). A magyar földgázrendszer 2017 évi adatai. http://mekh.hu/download/f/29/60000/a magyar_foldgazrendszer_2017_evi_adatai.pdf.

Mihályi, P. (2010). A magyar privatizáció enciklopédiája. Veszprém: Pannon Egyetemi Kiadó, MTA Közgazdasági Intézet.

Milieau, E. \& Law, A. (2018). Review of national rules for the protection of infrastructure relevant for security of supply. Forrás: https://ec.europa.eu/energy/sites/ener/ files/documents/final_report_on_study_on_national_ rules_for_protection_of_infrastructure_relevant_for security_of_supply.pdf

Newbery, D. (1999). Privatization, restructuring, and regulation of network utilities. Cambridge: The MIT Press. https://doi.org/10.7551/mitpress/5579.001.0001

OECD (2019). Sectoral Regulation: Energy, transport and communications. OECD Product Market Regulation Statistics (database). https://doi.org/10.1787/data-00596-en. 
Opolska, I. (2017). The efficacy of liberalization and privatization in introducing competition into European natural gas markets. Utilities Policy, 1-10. https://doi. org/10.1016/j.jup.2017.07.003

Sebestyén Szép, T. (2017). The Effects of Utility Cost Reduction on Residential Energy Consumption in Hungary - a Decomposition Analysis. International Journal of Sustainable Energy Planning and Management, 61-78. https://doi.org/10.5278/ijsepm.2017.13.5

Szolnoki, P. (2011). Baumgarten saga. REKK jelentés az energiapiacokról 2011/3, 9-11.

Valentiny, P. (2009). Piacnyitás a magyar hálózatos szolgáltatásoknál OECD-adatok tükrében. In P. Valentiny, F. Kiss, \& C. Nagy (szerk.), Verseny és Szabályozás 2009 (pp. 257-269). Budapest: MTA KTI.

Vince, P. (2008). Tulajdonosi koncentráció, vállalati összefonódás. Versenyfelügyeleti döntések és az energia- szektor vállalati szerkezetének alakulása. In P. Valentinyi, \& F. Kiss (szerk.), Verseny és Szabályozás 2007 (pp. 156-178). Budapest: MTA KTI.

Vince, P. (2011). Versenyélénkítés erőfölény-korlátozással: szabályozás és vállalatiszerkezet-átalakítás az Európai Unió energiapiacán. In P. Valentiny, F. Kiss, \& C. Nagy (szerk.), Verseny és Szabályozás, 2010 (pp. 329-353). Budapest: MTA KTI.

Vince, P. (2012). Árszabályozás s versenyhelyzet a magyarországi energiapiaci nyitás. In P. Valentiny, F. Kiss, \& C. Nagy (szerk.), Verseny és Szabályozás 2011 (pp. 303-326). Budapest: MTA KTI.

Zelei, G. (2018). Economics of Upstream Oil and gas. ERRA, Principles of Natural Gas Market Regulation, Budapest.

Zummo, P. (2018). Retail Electric Rates in Deregulated and Regulated States, 2017 Update. American Public Power Association.

\section{Végjegyzetek:}

A 2003. évi XLII. törvény a földgázellátásról

ii A Bizottság (EU) 2017/460 Rendelete (2017. március 16.) az összehangolt földgázszállítási tarifaszerkezetekre vonatkozó üzemi és kereskedelmi szabályzat létrehozásáról.

iii 2007. évi CXVI. törvény a közellátás biztonsága szempontjából kiemelkedő jelentőségű vállalkozásokat érintő egyes törvények módosításáról. 